\title{
EDITORIAL
}

\section{Growing the discipline of family medicine as a counterculture}

I would like to start this editorial with a word of thanks. Thank you to the Academy (SAAFP)'s leadership for entrusting my colleague, Professor Indiran Govender (Assistant Editor), and me with the responsibility and opportunity to build on the work done by our predecessors. A read through the editorials since the journal's birth in 1980 (available

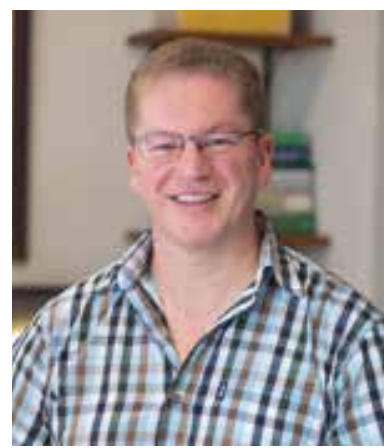
from: http://www.safpj.co.za) informed me of the innovative thinking behind building the discipline of family medicine and primary care over the past few decades.

One of the ways to grow a discipline, is through research. ${ }^{1}$ Socially relevant and ethically conducted research in family medicine and primary care is needed, and the SAFP journal will continue to serve as a suitable platform for communicating such research. Another core function of this journal is to provide review articles relevant to the learning needs of its readership (the SAAFP community, as well as primary care colleagues within South Africa and the wider African region). The new editorial board is being finalised in order to be representative of this readership. Editorial board members will assist the editors and the journal with peer review, promoting the journal and providing strategic direction to ensure that the journal remains relevant to the South African family medicine and primary care community. The board includes a member nominated by the Rural Doctors Association of South Africa (RuDASA), representatives from the South African training programmes, as well as international members who have demonstrated a commitment to growing the discipline within our region. I am pleased to announce the new editorial board (see Table 1) and look forward to work with you over the next few years.

Ultimately, growing a discipline is about ensuring that its core function is aligned with the health needs of society. These societal needs were articulated in various recent policy documents at national and international levels, notably the revisited Alma Ata declaration, ${ }^{2}$ the Sustainable Development Goals (SDGs) ${ }^{3}$ and South Africa's National Development Plan ${ }^{4}$. Universal health coverage (UHC) was included by the United Nations in the SDGs, and represents two fundamental and interconnected commitments: the equitable access to high-quality health services and the promise of financial protection for all. ${ }^{5}$ The WHO agrees that family doctors have a key role to play as members of the team-based approach to high-quality primary health care (PHC). ${ }^{6}$ This need for high-quality PHC is reiterated in the PHCPI framework ${ }^{7}$ and work done by the Lancet's commission on High Quality Health Systems ${ }^{8}$ (South Africa was represented on this commission).
Table 1: The SAFP journal editorial board, 2019 - 2023

\begin{tabular}{|c|c|}
\hline Board member & Affiliation \\
\hline \multicolumn{2}{|l|}{ South African members } \\
\hline Professor John Tumbo & $\begin{array}{l}\text { Sefako Makgatho Health Sciences } \\
\text { University }\end{array}$ \\
\hline Dr Michael Pather & Stellenbosch University \\
\hline Dr Tasleem Ras & University of Cape Town \\
\hline Professor Hanneke Brits & University of the Free State \\
\hline Professor Andrew Ross & University of KwaZulu-Natal \\
\hline Professor Gert Marincowitz & University of Limpopo \\
\hline Dr Lushiku Nkombua & University of Pretoria \\
\hline Professor Olufemi Omole & University of the Witwatersrand \\
\hline $\begin{array}{l}\text { Professor Parimalaranie } \\
\text { Yogeswaran }\end{array}$ & Walter Sisulu University \\
\hline Dr Adam Asghar & $\begin{array}{l}\text { Rural Doctors Association of South } \\
\text { Africa (RuDASA) }\end{array}$ \\
\hline \multicolumn{2}{|l|}{ International members } \\
\hline Dr Vincent Cubaka & University of Rwanda, Rwanda \\
\hline Professor Carl de Wet & Griffith University, Australia \\
\hline Professor Amanda Howe & $\begin{array}{l}\text { University of East Anglia, United } \\
\text { Kingdom }\end{array}$ \\
\hline Professor David Ponka & University of Ottawa, Canada \\
\hline Professor Val Wass & Keele University, United Kingdom \\
\hline Dr Kenneth Yakubu & University of Jos, Nigeria \\
\hline
\end{tabular}

The key ethos of our discipline, relationship-centeredness, becomes apparent when zooming in on our daily interaction with our patients. Viewing this essence of medicine as an "intensely personal matter" motivated Francis W Peabody in 1927 to state that, "the treatment of a disease may be entirely impersonal; (however) the care of a patient must be completely personal".9 This attention to the person behind the illness unifies us towards making family medicine the "counterculture" (coined by $G$ Gayle Stephens in 1989) ${ }^{10}$ within the presiding atmosphere of modern medicine. Attention to building relationships with our patients, our team members (which include students, allied health colleagues and an interprofessional approach to learning, practice and clinical governance $)^{11}$ and our community encompasses the core function of family medicine.

Our annual National Family Practitioners' Conference represents another opportunity to grow the discipline (register for the 2019 conference at http://saafp.org/conferences/index.php/ANFPC; remember to submit abstracts by 30 April 2019). During the 2016 conference, a workshop explored the potential futures for family medicine in South Africa and attendees agreed that the Academy should pursue a number of options:

- "The Academy as our professional body could engage more proactively with policy-makers in the Department of 
Health and the Treasury, and to develop skills in advocacy to communicate our vision more clearly. In particular to engage with the process of re-engineering primary health care and national health insurance. The voice of rural doctors and contribution of family medicine in rural areas needs to be more clearly articulated.

- The Academy could ensure that research evidence of the contribution of family medicine to the health system is showcased and communicated.

- The Academy could more confidently make the case for family medicine to the public through a marketing campaign and the general media.

- The Academy could use their journal, the South African Family Practice journal, to promote the viewpoint of the discipline.

- The Academy could actively foster the next generation of leaders and ensure that new ideas and people are involved in leading the profession." ${ }^{\prime 12}$

I would like to end by encouraging Academy members to use the South African Family Practice journal "to promote the viewpoint of the discipline", by submitting original research, opinion pieces, letters (both scientific and addressed to the editor), as well as highlighting learning needs to be addressed in the CPD section. You are welcome to engage with the \#SAFP journal (@SAFPjournal) and the Academy (@SAAFP1) via Twitter, which will assist the Academy with ensuring that "the contribution of family medicine to the health system is showcased and communicated".
Best wishes,

\section{Klaus B von Pressentin}

Editor-in-Chief

Twitter: @klausvon

\section{References:}

1. Beasley JW, Starfield B, van Weel C, Rosser WW, Haq CL. Global health and primary care research. J Am Board Fam Med. 2007;20(6):518-26.

2. Rifkin SB. Alma Ata after 40 years: Primary Health Care and Health for All-from consensus to complexity. BMJ Global Health. 2018;3:e001188.

3. Pettigrew LM, Maeseneer J De, Anderson MP, Essuman A, Kidd MR, Haines A. Primary health care and the Sustainable Development Goals. Lancet. 2015;386(10009):2119-21.

4. National Planning Commission. National Development Plan 2030: Our future make it work. Pretoria, South Africa: Presidency of South Africa; 2012.

5. Boerma T, Eozenou P, Evans D, Evans T, Kieny MP, Wagstaff A. Monitoring prog ress towards universal health coverage at country and global levels. PLoS Med. 2014;11(9):e1001731.

6. A vision for primary health care in the 21st century: towards universal health coverage and the Sustainable Development Goals. Geneva: World Health Organization and the United Nations Children's Fund (UNICEF); 2018. Available from: https:// www.who.int/docs/default-source/primary-health/vision.pdf. Accessed 21 March 2019

7. Bitton A, Ratcliffe $H L$, Veillard JH, Kress DH, Barkley S, Kimball M, et al. Primary Health Care as a Foundation for Strengthening Health Systems in Low-and MiddleIncome Countries. J Gen Intern Med. 2017;32(5):566-71.

8. Kruk ME, Gage AD, Arsenault $C$, Jordan $K$, Leslie HH, Roder-DeWan S, et al. Highquality health systems in the Sustainable Development Goals era: time for a revolution. Lancet Glob Health. 2018;6(11):e1196-252.

9. Peabody FW. The Care of the Patient. JAMA. 1927;88(12):877-82. Available from https://jamanetwork.com/journals/jama/article-abstract/245777. Accessed 21 March 2019

10. Stephens GG. Family medicine as counterculture. Fam Med. 1989;21(2):103-9.

11. Academy of Science of South Africa (ASSAf). Reconceptualising Health Professions Education in South Africa. 2018. Available from: http://dx.doi.org/10.17159/assaf.2018/0021. Accessed 21 March 2019

12. Mash R, Von Pressentin K. Family medicine in South Africa: exploring future scenarios. S Afr Fam Pract. 2017;59(6):224-7. 